\title{
Natural and Constructed Wetlands in Canada: An Overview
}

\author{
GAVIN KENNEDY ${ }^{1}$ AND TATIANA MAYER ${ }^{2 *}$
}

\author{
${ }^{1}$ Present address: Earth Sciences, University of Waterloo, Waterloo, Ontario N2L 3G1 \\ ${ }^{2}$ National Water Research Institute, Environment Canada, 867 Lakeshore Road, \\ Burlington, Ontario L7R $4 A 6$
}

\begin{abstract}
A review of freshwater wetland research in Canada was conducted to highlight the importance of these ecosystems and to identify wetland research needs. Both natural and constructed wetland systems are discussed. Natural wetlands are an important part of the Canadian landscape. They provide the habitat for a broad variety of flora and fauna and contribute significantly to the Canadian economy. It is estimated that the total value derived from consumptive and nonconsumptive activities exceeds $\$ 10$ billion annually. The past decades have witnessed the continued loss and degradation of wetlands in Canada. In spite of recent protection, Canadian wetlands remain threatened by anthropogenic activities. This review shows that more research on fate and transport of pollutants from urban and agricultural sources in wetland systems is needed to better protect the health and to assure the sustainability of wetlands in Canada. Furthermore, improved knowledge of hydrology and hydrogeochemistry of wetlands will assure more effective management of these ecosystems. Lastly, better understanding of the effect of climate change on wetlands will result in better protection of these important ecosystems.

Constructed wetlands are man-made wetlands used to treat non-point source pollution. The wetland treatment technology capitalizes on the intrinsic water quality amelioration function of wetlands and is emerging as a cost-effective, environmentally friendly method of treating a variety of wastewaters. The use of wetland technology in Canada is, however, less common than in the U.S.A. A number of research needs has to be addressed before the wetland treatment technology can gain widespread acceptance in Canada. This includes research pertaining to cold weather performance, including more monitoring, research on design adaptation and investigation of the effects of constructed wetlands on wildlife.
\end{abstract}

Key words: wetlands, Canadian wetlands, freshwater wetlands, constructed wetlands, wetland treatment

\section{Introduction}

Wetland ecosystems are vital to the social, economic and ecological health of Canada, and constitute a prominent feature of the Canadian landscape, representing approximately $14 \%$ of Canada's total land area, and an estimated quarter of the world's wetlands. Decades of research

* Corresponding author; tanya.mayer@ec.gc.ca 
have established wetland systems to be highly productive, unique ecotones, providing Canadians with a wide range of benefits and functional values. As transitional landscapes, wetlands occupy a pivotal role in the environment, buffering interactions between terrestrial and aquatic systems. They have been termed "nature's kidneys" (Mitsch and Gosselink 2000) due to the intrinsic natural functions they perform with respect to water quality improvements.

Although the recognition of the socio-economic and environmental significance of wetlands has increased in recent decades, historically they have been perceived as vast wastelands and have hence suffered from widespread loss and degradation. Approximately $70 \%$ of Prairie and southern Ontario wetlands have been converted for alternative land uses since European settlement, with agricultural reclamation representing $85 \%$ of Canada's wetland losses (SOCE 1991). As agricultural, urban, and industrial land-use pressures continue to favour the destruction and impairment of Canada's remaining wetlands, the implementation of appropriate protection measures and research initiatives will become critical to ensuring the health and sustainability of this threatened resource. Fortunately, wetland conservation and restoration efforts are gaining momentum as public perceptions of wetland values continue to evolve, and research continues to affirm the significance of these ecosystems in the Canadian environment.

Besides traditional values related to fish and wildlife habitat, Canadian researchers are exploring a number of non-traditional wetland values and uses. Substantial research efforts are currently directed towards the application of wetland treatment systems in removing contaminants from municipal and industrial wastewaters and from agricultural runoff (Berezowsky 1996; Cole 1998; Pries 1996). Constructed wetlands are emerging as an attractive, low-cost treatment alternative with many ancillary benefits. A better understanding of the complex dynamics of wetland systems and geochemical pathways is important to effectively implement this technology in Canada (Price and Waddington 1999). The objective of this paper is to present a comprehensive overview of constructed and natural freshwater wetlands in Canada, identifying research gaps and highlighting the importance of preserving the nation's wetland ecosystems.

\section{Wetland Classes, Characteristics and Distribution in Canada}

According to the National Wetlands Working Group (NWWG 1987), wetlands are defined as areas with the water table at, near, or above the land surface for a long enough period to promote hydric soils, hydrophytic vegetation, and biological activities adapted to wet environments. The definition of wetlands was changed briefly by Zoltai and Vitt (1995) and repeated later by Warner and Rubec (1997). The latest version (Warner and Rubec 1997) is presently considered as the official definition of wetlands in Canada. It defines the wetlands as, "land that is saturated with water long enough to promote wetland or aquatic processes as indicated by poorly drained soils, hydrophytic vegetation and various kinds of bio- 
logical activity which are adapted to a wet environment." The most common characteristic of all wetland types is an accumulation of partially decomposed organic matter, peat, which accumulates in wetlands due to high plant productivity, coupled with low decomposition rates. The high productivity of wetland systems is attributed to the high efficiency of wetland plants to fix carbon and create biomass through the process of photosynthesis. Other factors contributing to increased plant productivity include efficient assimilation and abundance of nutrients, and a surplus of moisture for plant growth. Low decomposition rates are observed in most wetlands due to anaerobic conditions in wetlands soils.

\section{Wetland Classification}

According to the Canadian wetland classification system, natural wetlands in Canada can be broadly divided into five distinct classes: bogs, fens, swamps, marshes, and shallow open water wetlands (NWWG 1987). The focus of this review paper is on the freshwater systems belonging to these five classes, which represent the majority of all Canadian wetland areas (NWWG 1987). Canadian wetlands have been divided into these classes based on "broad vegetation physiognomy, hydrology, and water quality" (Zoltai 1988). Table 1 summarizes the salient characteristics typical of each of the five wetland classes.

Water chemistry can also form the basis of wetland classification. Fens and swamps are classed as mineratrophic wetlands, receiving atmospheric and telluric inputs of nutrients, whereas bogs are ombrotrophic wetlands, receiving water and nutrients from direct precipitation (NWWG 1997). Other terms commonly used to describe Canadian wetlands include peatland, muskeg, prairie pothole, and slough. The term peatland refers to wetland areas with an accumulation of organic matter in excess of $40 \mathrm{~cm}$, whereas a muskeg consists of a large expanse of peatland or bog situated in northern Canada (Zoltai 1988). Tarnocai (1998) estimates that peatland systems represent over $90 \%$ of Canadian wetlands. Prairie potholes and sloughs, found predominantly in the Canadian Prairie region, are comprised of shallow, marsh-like ponds.

\section{Factors Influencing Wetland Development and Distribution in Canada}

Wetlands in Canada have developed gradually since the disappearance of glacier ice. Their regional distribution is governed primarily by climatic and morphometric factors (Zoltai 1988). Price and Waddington (1999) note that climatic influences on wetland distribution are best described by latitudinal and meridianal gradients. Latitudinal effects are largely related to the amount of incoming radiation, which controls productivity and decomposition rates, whereas meridianal effects are associated with precipitation patterns, which control the amount of available moisture. Morphometric influences on wetland development are related to the distribution of excess water (Zoltai 1988). For example, few wetlands are located in mountainous areas or on sloping surfaces due to rapid drainage, whereas wetlands commonly develop in surface depres- 


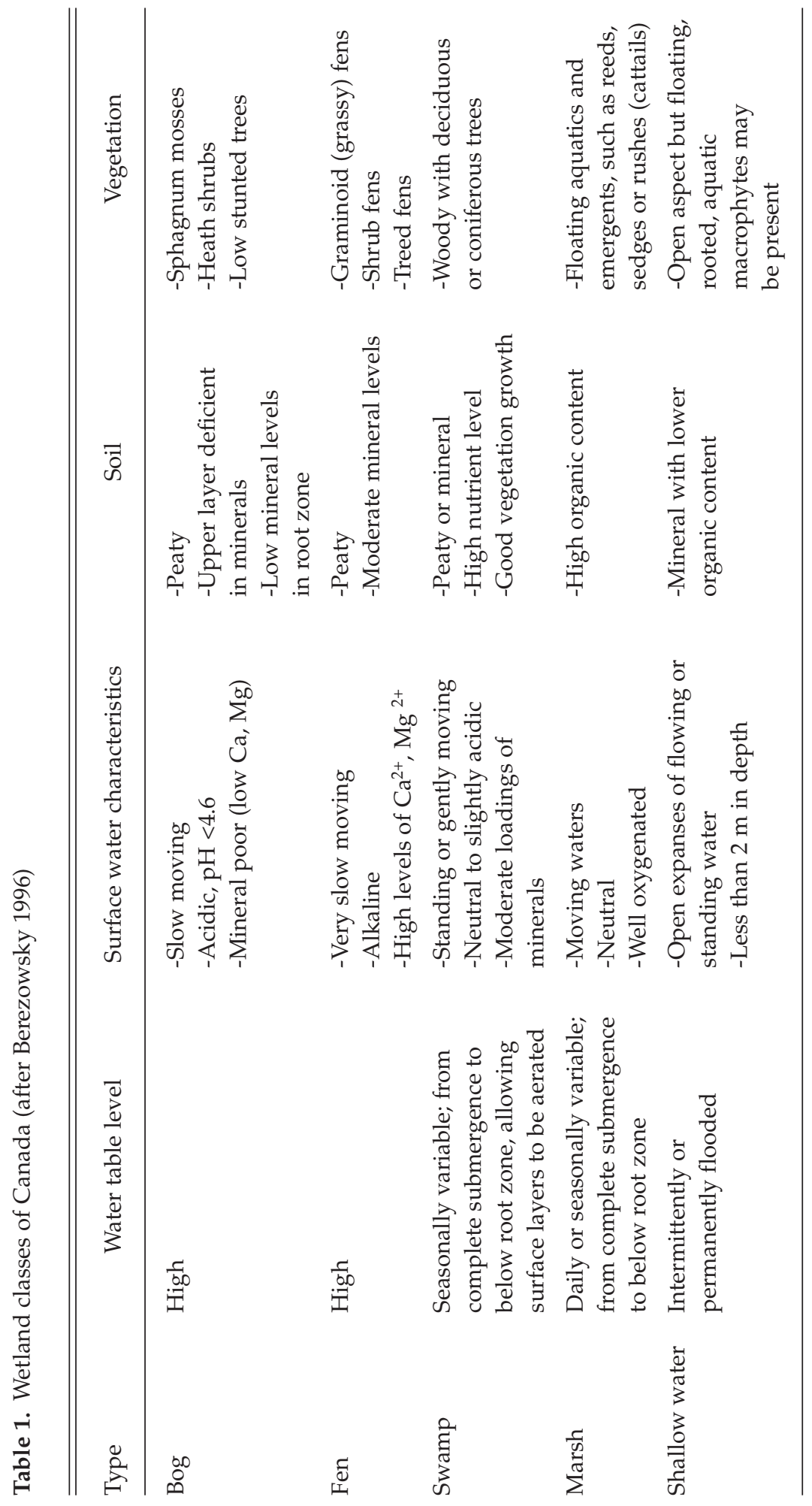


sions. This observation is supported by Graneiro and Price (1999) who showed that topography partially explained (22\%) the distribution of a blanket bog in Newfoundland. The availability of nutrients has also been found important in influencing wetland development (Zoltai 1988).

The development of wetlands in any particular location is determined by several interacting abiotic and biotic factors (Zoltai 1988), with hydrological processes, especially water level and hydroperiod, being the principal determinant of wetland form and function (Berezowksy 1996). Although they are generally stable over the long term, wetlands are dynamic systems that change continuously in response to variations in climate and hydrology. For example, a slight rise in water level can cause coastal wetlands to migrate inland and produce changes in wetland species composition according to varying tolerances of water depth. Some inland marshes, such as the prairie glacial marshes, follow a 5- to 20-year cycle of drought and re-flooding, with vegetation changing from dense stands of annual seedlings to perennial stands of marsh vegetation (Mitsch and Gosselink 1986).

The largest concentration of Canadian wetlands occurs in the Hudson Bay area, within the provinces of Ontario and Manitoba. The geographical distribution of Canadian wetlands is illustrated in Fig. 1. Some of Canada's better known freshwater wetlands include the marshes found along the shores of the Great Lakes and St. Lawrence River, the PeaceAthabasca and Red River deltaic wetlands, the prairie potholes, the peatlands of Quebec, Newfoundland and Vancouver Island, and the large areas of muskeg in Northern Canada.

\section{Function of Wetlands}

Wetland ecosystems perform a variety of essential functions, providing both direct and indirect anthropogenic benefits. Classification of wetland functions is difficult as wetland functions are diverse and interrelated, and wetland values and functions are interchangeable. For the purpose of this review, wetland functions are categorized as physical, chemical, and biological.

\section{Physical}

Physical functions of wetlands include flood mitigation, coastal protection, aquifer recharge, and sediment trapping. Wetlands intercept storm runoff, providing an important temporary storage medium for storm waters (Williams 1990). The storage and retention capacity of wetlands desynchronizes flood response, causing water to be slowly released to the main channel from numerous tributaries rather than all floodwaters entering the main channel simultaneously. Water level and stream velocity is consequently reduced, offering critical flood protection to downstream areas. The extensive drainage of prairie wetlands within the Red River floodplain has resulted in a net loss of this function and likely heightened the severity of the 1997 Red River flood in Manitoba (Richman 


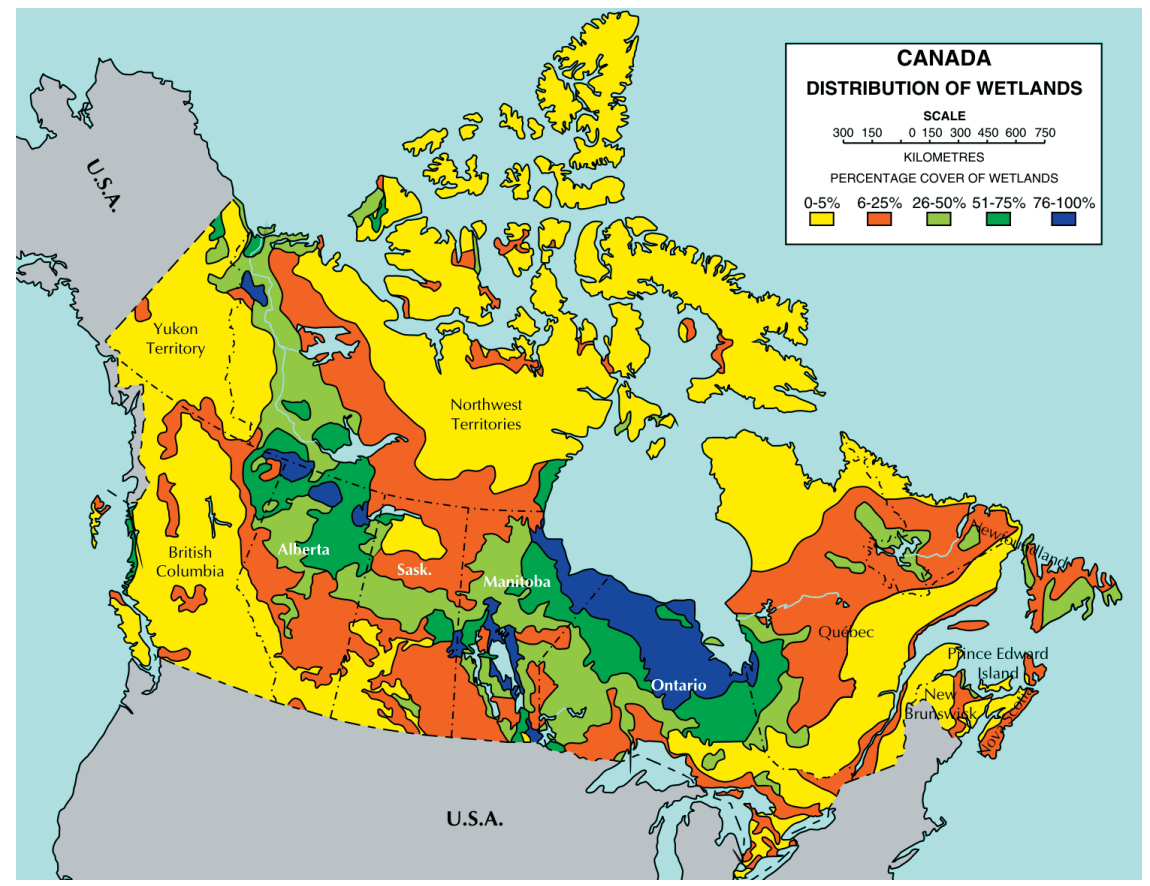

Fig. 1. Geographical distribution of wetlands in Canada. From: National Wetlands Working Group. 1986. Canada's Wetlands, Map Folio. Energy, Mines, and Resources Canada and Environment Canada. Ottawa, Ontario.

1997). Wetlands protect Canada's vulnerable coastal environments by providing a zone of vegetation, intermediate between land and water, which can attenuate wave and storm energy without sustaining any significant damage. Studies have shown that more than $50 \%$ of incident wave energy is dissipated within the first $2.5 \mathrm{~m}$ of a marsh environment (Williams 1990).

The magnitude of groundwater recharge ascribed to wetlands is not very well documented but it is believed that the majority of wetlands do not contribute significantly to groundwater supplies (Mitsch and Gosselink 1986). They can, however, play an important role in recharging groundwater resources in areas containing numerous small wetlands, such as the Canadian Prairies, which are dominated by small shallow marshes and sloughs (Van der Kamp and Hayashi 1998). Another important physical function of wetlands is sediment trapping. Wetlands filter suspended solids and reduce shoreline erosion by trapping sediment-laden runoff discharging into adjacent water bodies. They 'trap' sediment by reducing flow velocities, encouraging sediment to settle out of suspension in the water column and accumulate in the wetland substrate. The water clarity of adjacent water bodies is thereby improved. This sedimentation process can also remove BOD from runoff water, and pathogens and pollutants adsorbed to suspended solids. Shorelines are further stabilized and pro- 
tected from erosive processes by the vegetative growth and root systems associated with wetland development. Canadian experiences relating to a bio-engineered approach to shoreline management and erosion control are poorly documented in the available literature.

\section{Chemical}

Chemical functions of wetlands include contaminant removal and global geochemical cycling. Wetlands behave as unique transitional zones between upland areas and water bodies, effectively regulating pollutant and nutrient loadings to receiving waters through a number of chemical and biological mechanisms. Although the majority of wetlands act as a sink, Reddy and Gale (1994) found that wetlands behave as a source, sink, or transformer of pollutants and nutrients depending on the chemical, physical, and biological characteristics of the wetland environment. Numerous studies corroborate this phenomenon, including a study by Devito (1995) which demonstrates that the catchment hydrogeology of Canadian Shield wetlands exerts a significant influence on sulphate retention in wetlands.

\section{Water quality}

One of the most important chemical functions of wetlands is water quality amelioration. A variety of chemical and biochemical processes, such as microbial degradation, assimilation, precipitation, and adsorption to soil particles operate within the wetland environment, contributing to improved water quality. Wetland vegetation augments microbial activity by maintaining an extensive root and leaf substrate for bacterial 'biofilms,' and by providing an additional source of dissolved oxygen (Reimold and McBrien 1997). Wetland plants are uniquely adapted to anaerobic soil conditions, transporting oxygen to the root zone through specialized structures called aerenchyma. Oxygen is produced as a byproduct of wetland plant growth, resulting in higher dissolved oxygen concentrations in the water and in the soil immediately surrounding the plant roots. The presence of these oxidized microsites enhances the system's capacity for aerobic bacterial decomposition of pollutants. Furthermore, deposition of iron oxide plaque on the oxidized microsites ameliorates the toxic effects of metals such as copper and nickel on plant growth (Greipsson and Crowder 1992). Greipsson and Crowder (1992) found that the formation of iron oxide plaque on the roots of rice increased the plant biomass, in spite of exposure to copper, and prevented the plants from development of chlorosis, necrosis, or both.

Biological oxygen demand is removed from runoff water through both aerobic and anaerobic microbial degradation processes (Berezowsky 1996). Nitrogen is removed by microbial conversion of nitrogen compounds to nitrate by Nitrosomonas bacteria in the aerobic layer (nitrification) and subsequent microbial reduction to nitrogen gas by Nitrobacter in the anaerobic layer of the wetland (denitrification). The ability of natural wetlands to attenuate high nitrate concentrations is documented in 
numerous studies, including a study of agricultural runoff in the Boyne River, in Alliston, Ontario, where significant nitrate removal was observed in a riparian wetland (Heagle et al. 1998). Other nitrogen removal processes include ammonia volatilization and plant uptake (Reddy and Burgoon 1996).

Wetlands remove nutrients (organic $\mathrm{C}, \mathrm{N}$ and $\mathrm{P}$ ) for biomass production through absorption and assimilation by plants. Plant uptake is reported to be the principal mechanism for organic phosphorus removal in wetlands (Patrick 1994), whereas the principal mechanism for inorganic phosphorus removal is adsorption and precipitation in the root bed media (Berezowsky 1996). It is important to note that phosphorus, the limiting nutrient in most freshwater ecosystems, is retained by wetland systems and does not undergo atmospheric exchanges (Reddy and Burgoon 1996). Hence, a number of studies have focused on the processes and factors regulating phosphorus retention in wetlands (Reddy et al. 1999). In a recent survey of data from North American wetlands, Richardson and Qian (1999) concluded that the threshold phosphorus loading, which North American wetlands are able to tolerate is $1 \mathrm{mg} \mathrm{P} / \mathrm{m}^{2} /$ year. Uptake and removal of plant nutrients, especially phosphorus, limits the growth of algae and other undesirable aquatic plants and reduces eutrophication and noxious algal blooms, which are a problem in many Canadian waterways. Algal growth depletes the dissolved oxygen levels of deeper waters, and thereby reduces the water body's capacity to support aquatic life. These effects have been studied extensively in Canada, most notably in Lake Ontario environments such as the Bay of Quinte (SOCE 1991).

Wetlands remove contaminants, such as heavy metals, herbicides and pesticides from runoff water primarily through adsorption on the organic and clay sediments and through biotransformation of pollutants by a diverse community of wetland organisms. Trace metals can readily form complexes with the organic matter contained in wetland sediments, as organic soils have been shown to have a high cation exchange capacity (Berezowsky 1996). A review of water quality amelioration by natural wetlands (Sobolewski 1997) showed substantial retention of metals and metalloids by wetland sediments. Natural wetlands downstream of abandoned mine sites, such as Mount Washington (Kwong and Stempvoort 1994) and Silver Queen mines in British Columbia, and Cluff Lake mines in Saskatchewan (Sobolewski 1997), show significant removal of a variety of metal species from water, including $\mathrm{U}, \mathrm{Cu}, \mathrm{Al}$, and $\mathrm{Zn}$. Pathogenic contaminants, such as bacteria and viruses, are removed and deactivated in wetland systems through sorption to sediments, excretion of antibiotics from the roots of macrophytes, UV radiation, and predation by other organisms (Berezowsky 1996).

\section{Global biogeochemical cycles}

In terms of broad-scale processes, wetlands play an important role in global cycles. Due to high productivity and low decomposition rates, wetlands, particularly peatlands, sequester an enormous volume of carbon, 
acting as a net global carbon sink. While wetlands occupy only about $6 \%$ of the world's land surface (Mitsch and Gosselink 2000), they contain 14\% of the terrestrial biosphere carbon pool (North American Wetlands Conservation Council [NAWCC], Canada). Wetlands represent a longterm carbon sink because $\mathrm{CO}_{2}$ is removed from the atmosphere for plant growth faster than it is released from decomposing plant matter. Armentanao and Menges (1986) estimate that temperate organic soil wetlands absorbed between $57 \times 10^{6}$ and $83 \times 10^{6}$ tonnes/year of carbon before the occurrence of widespread wetland reclamation. Carbon sequestration is especially important in northern peatlands, which contain an estimated $500 \times 10^{15}$ tonnes of organic carbon, binding approximately $23 \mathrm{~g} \mathrm{C} \mathrm{m}^{-2} \mathrm{yr}^{-1}$ (Gorham 1991). As the concentrations of carbon dioxide in the atmosphere are steadily increasing due to the burning of fossil fuels and clear-cutting of tropical forests (Mitsch and Gossselink 2000), the importance of wetlands in the global carbon cycle is increasing. Wetlands are also a net source of atmospheric methane due to anaerobic decomposition of organic material.

Besides carbon, wetlands also have a significant role in global cycles of nitrogen and sulfur (Mitsch and Gossselink 1986). Sulfates that are transported into wetland environments through direct precipitation and runoff are reduced to sulfides. Most of the reduced sulfides subsequently form insoluble complexes with metal ions, however, some are released to the atmosphere as hydrogen, methyl and dimethyl sulfides. Emission of $\mathrm{H}_{2} \mathrm{~S}$ to the atmosphere from southern freshwater wetlands ranges between 0.004 to $2.6 \mathrm{~g} \mathrm{~S} \mathrm{~m}^{-2} \mathrm{yr}^{-1}$ (Mitsch and Gosselink 2000). Wetlands are also important in nitrogen cycling by volatilizing excess nitrogen (as $\mathrm{N}_{2} \mathrm{O}$ and $\mathrm{N}_{2}$ ) from fertilizer-enriched agricultural runoff through denitrification processes. As the anthropogenic input of nitrogen into the land-based cycle increases through the manufacturing and use of fertilizers, increased use of nitrogen-fixing crops and burning of fossil fuels (Vitousek et al. 1997), the role of wetlands to serve as "sinks" for nitrogen is being widely investigated (Mitsch and Gosselink 2000).

\section{Biological}

Biological functions of wetlands include productivity, wildlife habitat, biodiversity and life support. Wetlands have an extremely high biological yield, rating as some of the most productive ecosystems in the world relative to their land area. They contribute disproportionately to the world's primary productivity, accounting for $24 \%$ of global primary productivity from $6.4 \%$ of the world's land surface (Williams 1990).

Wetlands are important reservoirs of biodiversity. Canadian wetlands are home to 600 species of flora and fauna. They provide habitat for a wide range of plants, fish, birds and other wildlife, including one-third of Canada's endangered and vulnerable species. In Ontario, a total of $86 \%$ of endangered species depend on wetlands for their survival (SOCE 1991). Wetlands in the Carolinian region of Ontario are especially important sanctuaries for endangered species. The Point Pelee marsh in the 
lower Great Lakes is reportedly the most biodiverse ecosystem in Canada. It also harbours the most endangered, threatened and rare species, such as the flying squirrel, the eastern hognose snake, the Carolinian wren, and the least bittern. Avian species at risk, such as the whooping crane, the white pelican, and the Caspian tern utilize prairie wetlands.

As life-support systems, wetlands provide critical nesting and feeding habitats for birds, and suitable spawning and nursery grounds for fish and shellfish. Mammals, such as beavers, otters, bobcats, and lemmings inhabit the marsh environment, and fish, such as stickleback and pike spawn and feed in the shallow marsh waters. A total of over 155 different species of birds, 50 species of mammals, and a multitude of plant species are dependent on Canada's wetlands for survival, which is an excellent indicator of the biodiversity associated with these ecosystems (Rubec et al. 1988).

Wetlands comprise especially important habitats for North America's migrating waterfowl along four major flyways (Pacific, Central, Mississippi, and Atlantic), and it is estimated that over 45 species of waterfowl depend on Canadian wetlands (Rubec et al. 1988). Atlantic Canada is recognized as an important breeding and staging area for black ducks and geese, whereas Quebec and Ontario are important breeding grounds for black ducks and mallards. The provinces of Quebec and Ontario are also recognized as important migration routes for many populations of geese and diving ducks. Meanwhile, the Canadian Prairies constitute a major breeding area to about 50\% of North America's duck population (Batt et al. 1989).

\section{Wetland Utilization}

A discussion of wetland uses necessarily equates wetland function to derived human benefit. This section attempts to differentiate the more passive functions listed above from active anthropogenic uses of wetlands. The total value derived from consumptive and non-consumptive activities, in addition to the natural functions of Canada's wetlands, is estimated to exceed $\$ 10$ billion annually (Rubec 1992).

\section{Consumptive Uses}

Consumptive uses of wetlands in Canada include food production, horticultural peat harvesting, forest harvesting and recreational hunting and fishing. Direct agricultural use of wetlands in Canada is limited mostly to the production of wild rice, cranberries and wild blueberries (Herdendorf 1992), whereas aquacultural fish farming is reportedly a growing industry in Western Canada (Rubec et al. 1988). In 1998 the Canadian cranberry industry was valued at \$55.4 million/year, with production focused in B.C. and Quebec, and the wild blueberry industry was valued at \$50.9 million/year, with production focused in Nova Scotia and Quebec (Agriculture Canada 1999). More important to Canadian agriculture, however, is the creation of new high-yield soils through drainage of 
wetland areas. Wetlands are drained and transformed into agricultural land because they offer high organic matter content, high nutrient levels and availability, and easily cultivated land, which translates into high agricultural yields (Reddy and Gale 1994). Peat harvesting, primarily for horticultural use, sustains a $\$ 100$ million/year Canadian industry (NAWCC 1996), whereas hardwood swamp forestry may contribute as much as $\$ 525$ million/year to the Canadian economy (Rubec et al. 1988).

The importance of wetlands to sustaining commercial fisheries in Canada is readily apparent from a number of case studies. A case study by Derksen and Gillies (1985) attributed the production of 150,000 youngof-the-year northern pike to the Sakarem marshes of the Saskatchewan River Delta, with northern pike productivity ranging from 0.5 to $2.3 \mathrm{~kg} / \mathrm{ha}$. Although a comprehensive monetary assessment of the contribution of wetlands to Canadian fisheries has not been performed, an interpretation of 1983 Fisheries and Oceans and Statistics Canada data, values the contribution of Canadian freshwater wetlands to fisheries at approximately $\$ 23$ million/year (Rubec et al. 1988). Wetlands contribute significantly to the commercial and recreational fishing industry by providing a spawning and feeding habitat for fish.

Waterfowl hunting is another popular consumptive use of wetlands in Canada. By harbouring an abundance of waterfowl, wetlands support a substantial recreational hunting industry. Total economic benefits of waterfowl were assessed to be $\$ 118$ million/year in Canada according to an Environment Canada report (Rubec et al. 1988). In a literature review of wetland valuation, Bardecki (1999) identifies several Canadian case studies that report on the economic benefits of wetlands. Benefits derived from duck hunting, based on estimates of willingness to pay, were determined to be approximately $\$ 100 /$ ha in a case study of 6897 ha of prairie pothole wetlands (Young and Thompson 1990). Comparatively, an economic study performed on Walpole Island, Ontario, determined that revenues for hunting, trapping and fishing in the natural wetlands produced an estimated net profit of \$168.52/ha (Elliot and Mulamoottil 1992).

\section{Non-consumptive Uses}

Non-consumptive uses and values of wetlands are much more difficult to quantify than consumptive uses. Non-consumptive uses of wetlands include aesthetic, recreational, educational, archaeological, scientific, and heritage uses. The annual return value of non-consumptive recreation in Canadian wetlands is estimated to be more than $\$ 3$ billion/year (Rubec et al. 1988). Numerous recreational activities, such as bird watching, are enjoyed in Canadian marsh environments. A case study on the local economic impact of bird watchers was estimated to be $\$ 3.2$ million annually in a 1987 study of Point Pelee marsh (Hvenegaard et al. 1989). The diversity and complexity of wetlands makes them preferred sites for research and many wetland parks such as Point Pelee National Park are popular recreational spots, boasting over half a million visitors every year. Other popular national parks containing large wetland areas include 
Long Point National Park (Ontario), Kouchibouguac National Park (New Brunswick), Cap Tourmente National Wildlife Area (Quebec) and the lower Fraser Delta (British Columbia).

\section{Anthropogenic Impacts}

Human activities have resulted in the widespread loss and degradation of wetland areas, and significant changes to the dynamics of Canadian wetlands. The pressures of urbanization, local economics, and politics increasingly favour the destruction and impairment of wetlands near urban centres. Meanwhile, pressures to increase the amount of arable land and food production results in continued reclamation of wetlands for agricultural land use, particularly in the prairie and Great Lakes basin regions (SOCE 1991). The potential effects of human-induced climate change on wetlands, and the potential contribution of wetland destruction to the greenhouse effect, is also well recognized by the scientific community (Franzen 1992). These anthropogenic impacts threaten the health and sustainability of Canada's wetlands.

There exist a limited number of studies that address the fate and effects of urban contaminants, such as road salts, on urban wetlands. Similarly, the direct effects of farming practices on the water quality of wetlands remains poorly addressed in the scientific literature. A project called WEVS (Wetland Ecosystem Vulnerability Study) has been initiated by the Canadian government to examine the relationship between wetlands, agricultural and urban land-use practices, climate change and increased ultraviolet radiation.

\section{Direct Effects}

Anthropogenic activities may have direct and indirect effects on wetlands. Drainage of wetlands for a variety of uses such as forestry, agriculture, peat harvesting, or land reclamation is probably the most prevalent example of a direct anthropogenic impact on wetlands. In most cases, a comprehensive cost-benefit analysis of wetland drainage that properly accounts for the replacement value of wetland functions is not performed prior to drainage (Rubec et al. 1988). Drainage operations cause a lowering of the water table and enhanced soil aeration, which is associated with increased subsidence, bulk density and water retention (Price 1997). The ecological function, hydrology and hydrochemistry of the wetland are thereby impaired.

Research is presently being conducted in Canada to restore peatlands that have been subjected to drainage and harvesting activities. Studies in the Lac St. Jean region of Quebec have shown that the amelioration of surface moisture conditions is essential to re-establishing Sphagnum mosses, the primary peat-forming vegetation (Price and Waddington 1999). Restoration strategies involve a number of techniques that will allow recolonizing Sphagnum mosses to draw moisture out of the peat profile, such as the creation of open water spaces and the application of a mulch cover. 
Land clearing and subsequent erosion, point and non-point source pollution, and hydrological modifications have all impacted the chemical cycling and water quality of wetland systems. The high rates of soil erosion resulting from land clearing and intensive agricultural land use, have resulted in increased deposition of sediments in Canada's lowland wetland areas (SOCE 1991). Increased sedimentation rates can augment biological oxygen demand and significantly alter the hydrologic regime of the wetland. The loss of wetland areas in Cootes Paradise and the Oshawa Second Marsh due to increased sediment loading is well documented (Crowder and Bristow 1988). A concomitant increase in turbidity in these wetlands prevents light from reaching submerged macrophytes. The virtual disappearance of submerged vegetation occurs at turbidity values of greater than 50 FTU (Sproule-Jones 1997).

Moreover, runoff of fertilizers, pesticides and salts leached from soil, and contaminants such as oils, trace organics, PAHs, and metals adversely affect water quality and nutrient cycling in wetlands. Some of these metals may bioaccumulate in the wetland environment, impairing the health of the wetland biota. In a comparative study of Oshawa Second Marsh, Rattray Marsh, and Cootes Paradise, Glooschenko (1978) found elevated sediment concentrations of a number of metals of concern including $\mathrm{Cu}, \mathrm{Ni}, \mathrm{Cd}, \mathrm{Zn}$ and $\mathrm{Pb}$. A study conducted in southeastern Ontario found that there existed a negative correlation between wetland species richness of all taxa except mammals and the density of paved roads located on lands up to $2 \mathrm{~km}$ from the wetland (Findlay and Houlahan 1997). Similarly, Sproule-Jones (1997) describes elevated sediment concentrations of PAHs in wetlands near major roadways.

Hydrological modifications, such as dams and stream channelization, affect water levels and circulation in wetland areas, changing flood frequencies and depriving wetlands of nutrient inputs (Mitsch and Gosselink 1986). Neill (1995) found that changes to the spring inundation pattern of marshes in Manitoba significantly affected the pattern of nitrogen cycling by the marsh. The development of hydro-electricity reservoirs, such as the Peace-Athabasca River Delta and James Bay hydroelectric projects, can also have deleterious effects on wetland areas. The construction of the Bennett Dam and streamflow control has prevented the occurrence of major flooding in the Peace-Athabasca River Delta since 1974. As a result, 50,000 acres of mudflats have been exposed and marsh vegetation has been replaced by grassland and willow scrub (Rubec et al. 1988).

Fills, dredging, dikes, water level stabilization and invasion of exotic species also currently threaten Canadian wetlands. The aggressive nonnative species are displacing native grasses, sedges and rushes. Burgeoning purple loosestrife populations have resulted in a loss of native flora and fauna in many Canadian wetlands including Point Pelee National Park (Dunster 1990) and many prairie sloughs (Ali 1992). In Point Pelee, almost 38\% of all plant species are considered exotic or nonnative. Other invasive species threatening the health of Canadian wetlands include curly pondweed, marsh cress, black alder, great manna grass, and yellow flag. 


\section{Indirect Effects}

Wetland ecosystems are very sensitive to environmental change. Shifts in global temperature or precipitation patterns could cause significant changes in wetland distribution, extent and functioning (Price and Waddington 1999). Even a slight increase in global temperature could cause the collapse of permafrost structures, causing a northward migration of wetland development or a lowering of the water table in certain wetland areas (Price and Waddington 1999). A lowering of the water table is associated with increased $\mathrm{CO}_{2}$ production, lower $\mathrm{CH}_{4}$ fluxes, and lower DOC fluxes (Moore et al. 1998). A net increase in atmospheric $\mathrm{CO}_{2}$ may result, intensifying the greenhouse effect. Human disturbances to peatlands, such as harvesting, may also increase atmospheric $\mathrm{CO}_{2}$ concentrations (Franzen 1992).

Presently, the production of $\mathrm{CH}_{4}$ by wetlands approximately balances the consumption of $\mathrm{CO}_{2}$ on a mass basis because $\mathrm{CH}_{4}$ is a much more effective greenhouse gas (Moore et al. 1998). It is evident that carbon storage is sensitive to hydrology, and due to the complexity of hydrological changes in peatlands under a doubling of $\mathrm{CO}_{2}$ climate scenario, a variety of responses are possible (Price and Waddington 1999). Despite their important role in carbon cycling, wetlands are often excluded from many global models on the effects of ecosystem functioning and carbon budgets on climate change. Their exclusion is the result of inadequate modelling of wetlands under contemporary conditions (Moore et al. 1998).

\section{Wetland Protection in Canada}

The importance of wetland conservation, restoration and protection as a fundamental aspect of federal government decision making is formalized in The Federal Policy on Wetland Conservation, which has been recently adopted by the Government of Canada. The Government of Canada is promoting a non-regulatory, cooperative approach to achieve a number of goals related to wise and sustainable use of wetlands in Canada. Goals of this approach include maintaining the benefits derived from wetlands throughout Canada and no net loss of wetland function on federal lands (Rubec 1992). A total of 35 Canadian sites have been designated as wetlands of international importance under the RAMSAR convention. The division of jurisdictional responsibilities regarding wetlands is complex and is currently shared among all three levels of government. The exercise of this jurisdiction rests with myriad pieces of legislation, including the Fisheries Act and the Constitution Act.

Another government initiative called the Great Lakes Wetlands Conservation Action Plan (GLWCAP) has been established to protect wetlands in the Great Lakes basin. Almost 3000 ha of wetlands have been protected and over 500 ha of wetlands have been rehabilitated since the project's inception in 1993. The long-term goal of the GLWCAP is to protect 30,000 ha of wetland habitat in the Great Lakes Basin over the next 25 years. Options to prevent further loss of wetlands include adding sediment to coastal wetlands to protect the wetlands from the 
rising water levels, planting grasses to protect coastal sands from erosion, building dikes or barrier islands, and controlling water levels artificially (Krieger et al. 1992).

Mitsch and Wilson (1996) report mixed results in the creation or restoration of wetlands to mitigate wetlands losses in the U.S., and advocate the following three guiding design principles to improve the likelihood of success: 1) understand the wetland function; 2) give the system time; and 3) allow self-design. Replacement wetlands are often built in human-altered watersheds that lack the suitable hydrology for created wetlands to succeed. Moreover, the success of wetland creation is measured according to unrealistic timelines that do not reflect the stochasticity of nature. To increase the survivability of wetland plant species, Mitsch and Wilson (1996) recommend transplanting and seeding with multiple species, thus allowing nature to participate in the wetland design.

\section{Constructed Wetland Treatment Systems}

Constructed wetlands are man-made wetlands designed to intercept and remove a wide range of contaminants from water. They use natural mechanisms to remove the contaminants before they reach the receiving waters. The constructed wetlands have gained acceptance in North America as a cost-effective, efficient treatment alternative due to their inherent ability to attenuate contaminant flows, conserve natural resources, reduce the flood hazard and erosion, and create wetland habitat. Because of these benefits, they are being used increasingly to treat a variety of wastewaters. Wetland systems have been applied to treat point and non-point source pollution, such as municipal storm water, combined, primary, secondary, and septic sewage, and industrial and agricultural wastewater. Research efforts to date have concentrated on municipal wastewater treatment and acid mine drainage (AMD), although interest in using constructed wetlands to treat agricultural and industrial wastewaters is growing (Berezowsky 1996).

\section{Growth and Distribution of Treatment Wetland Technology}

The "rapid growth of wetland treatment systems appears to be part of a global movement that supports more resource conservation and greater reliance on natural ecological processes in preference to the energy and chemical intensive systems currently in use" (Berezowsky 1996). Laboratory work involving wetland treatment technology originated in Germany almost 50 years ago by Kathe Seidel at the Max Planck Institute, and small-scale systems are now used extensively throughout Europe. There are over 6000 constructed wetlands in Europe and the United Kingdom (Knight and Kadlec 2000), consisting primarily of reed beds (Phragmites australis). In comparison, North America hosts over 1000 treatment wetlands (Knight and Kadlec 2000), most of which are located in the United States and are employed for large-scale treatment of municipal wastewater (Cole 1998). 
Relative to the European nations and the United States, Canada has been slow to adopt constructed wetland technology as a viable treatment approach. According to a 1994 inventory, a total of 67 natural and constructed wetlands have been developed in Canada to treat a variety of waste streams, not including acid mine drainage (Pries 1996). A variety of treatment wetlands was designed and constructed by CH2M Gore \& Storrie Limited (CG\&S). Their projects in Canada include wetlands for municipal wastewater, industrial discharges, and wetlands for stormwater/livestock wastewater treatment (Gore \& Storrie Limited 2000). Based on the results of pioneering studies performed in Listowell, Ontario, in the 1980s (Herskowitz 1986), municipal treatment systems have been piloted in small Ontario communities such as Cobalt, Cochrane, Port Perry (Berezowsky 1996), and town of Brighton (Gore \& Storrie Limited 2000). More recently, several large- and small-scale municipal wetland treatment systems have been implemented throughout Canada, including a large-scale plant (1246 ha) in Frank Lake, Alberta, and a small-scale plant (23.5 ha) in the town of Estevan, Saskatchewan (Pries 1996). Studies on AMD treatment using wetlands have also been performed in Canadian locales such as Cape Breton (Kalin and Scribailo 1989), Elliot Lake (Fyson et al. 1991), and Smithers, B.C. (Sobolewski 1996), although no full-scale systems are currently operational. Floating wetland mats of Typha were used in AMD treatment ponds (central Newfoundland and northern Ontario) and in settling ponds of coke stockpile runoff (northern coastal British Columbia) to augment the removal of particulate matter by Smith and Kalin (2000). The dense root system, with surface area of $11 \mathrm{~m}^{2}$ per $\mathrm{m}^{2}$ of mat trapped $0.3 \mathrm{~kg}$ of particulates per $\mathrm{m}^{2}$ (Smith and Kalin 2000).

A number of other treatment wetland applications have also been explored in Canada. Pilot studies in Storrington (Berezowsky 1996) and Sarnia (Higgins and Lugowski 1996) are being conducted to investigate constructed wetland treatment of landfill leachate. A treatment wetland with a working volume of approximately $3000 \mathrm{~m}^{3}$ was constructed to polish effluent from the on-site municipal lagoon at Ontario Power Generation Plant (OPG) at Nanticoke (McKenna et al. 2000). The Great Lakes 2000 Clean-up Fund has supported several constructed wetland projects for municipal stormwater treatment in Emery Creek (Toronto), Markham, Aurora and Scarborough (Shaw et al. 1996). Agricultural wastewater treatment is a growing application of treatment wetlands. To date, nine systems have been built in Ontario to treat livestock wastewater (Cole 1998) and over 30 systems have been constructed in Canada and the U.S. to treat milkhouse wastewater (Serodes and Normand 1999). Two treatment wetlands, consisting of runoff collection system, a storage pond and vegetated wetland treatment cells were constructed in Interlake area, Manitoba, to treat up to $63 \mathrm{~m}^{3}$ / day of waste from livestock industry (McGarry and Pries 2000). The preliminary results (McGarry and Pries 2000) reported effective removal of BOD, nitrogen, phosphorus and bacteria in these wetlands. In P.E.I., Cavendish Farms is using natural wetlands to polish effluent from its potato processing plant (Pries 1996). A summary of treatment wetlands in Canada is provided in Table 2. 


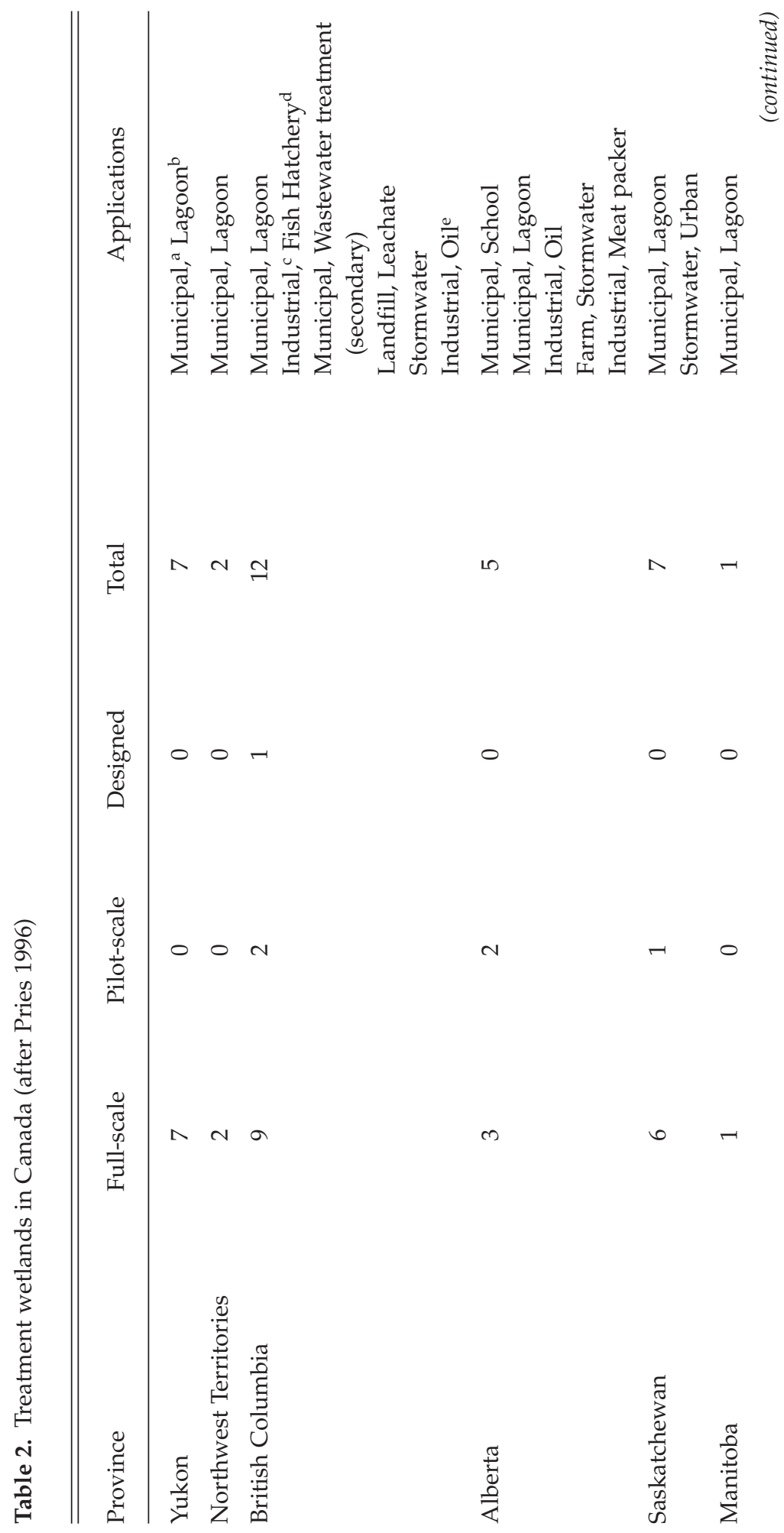




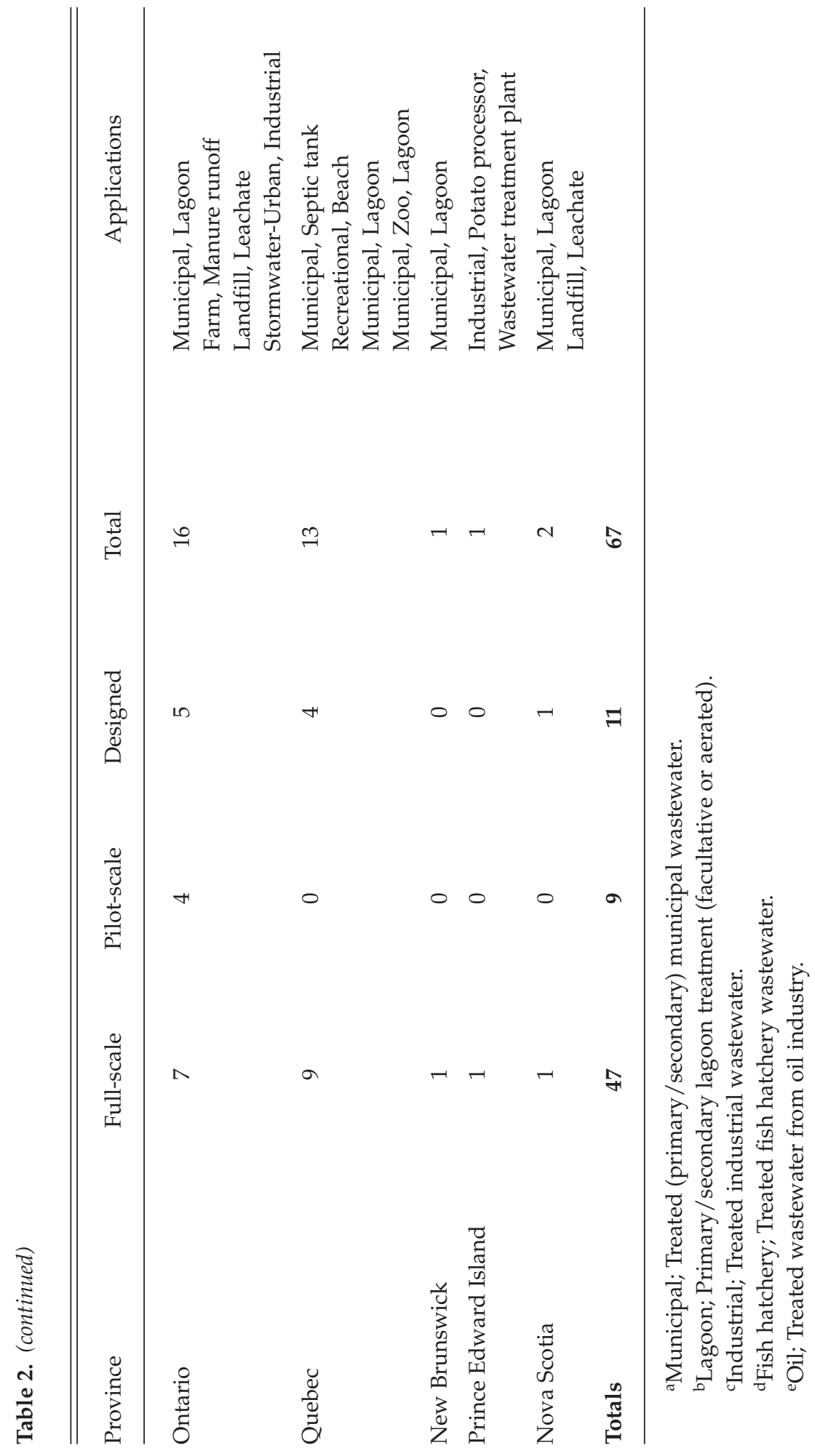




\section{Constructed Wetland Treatment}

Constructed wetlands are preferred over the less expensive, natural wetland treatment alternatives for several reasons. Constructed wetlands can be engineered according to site-specific treatment goals, whereas the treatment capacity of natural wetlands is highly unpredictable and can exhibit extreme variability when compared to constructed systems. Moreover, the use of natural wetlands for wastewater treatment can seriously impair the natural wetland's functions, and it is therefore recommended by several authors that natural wetlands be preserved for other multi-functional values and not be used for wastewater treatment (Hammer 1991; Berezowsky 1996; Campbell and Ogden 1999).

Constructed wetlands remove contaminants by several different means, combining physical, chemical, and biological treatment mechanisms (Table 3). Physical/chemical removal is effectuated through filtration, settling, precipitation, volatilization, complexation and adsorption (Taylor 1992). Biological processes such as plant uptake and bacterial degradation offer further opportunities for contaminant removal. The accretion of new sediments on the wetland substrate provides a mechanism for the long-term retention of nutrients and pollutants (Kadlec 1992). The accumulation and stability of these sediments, however, is regulated by the decomposition and physico-chemical properties of the newly formed sediments and native soils (Reddy and Gale 1994). Reed et al. (1993) notes that the effectiveness of constructed wetland technology in removing contaminants depends on a number of factors including hydraulic or pollutant loading, contact time, pollutant type, vegetation type, and ambient environmental conditions. Similarly, Gearheart (1992) describes wetland treatment performance as a function of retention time and the capacity of the vegetation and sediments to retain and/or cycle certain constituents.

A 1993 survey (Cole 1998) of over 300 constructed wetland cells operating in North America documented average performance levels of a 73\% reduction in BOD to $8 \mathrm{mg} / \mathrm{L}$, a $72 \%(13 \mathrm{mg} / \mathrm{L})$ reduction in TSS, a $53 \%$ $(4.5 \mathrm{mg} / \mathrm{L})$ reduction in nitrogen and a $56 \%(1.7 \mathrm{mg} / \mathrm{L})$ reduction in total phosphorus. The results of this survey have been incorporated into a North American Treatment Wetlands Database, which provides a unified basis for designing future treatment wetlands in North America. It should be noted that these average performance levels reflect a reporting bias, because the majority of wetland treatment systems are situated in the U.S. $(>90 \%)$ and are used for municipal wastewater treatment. Performance summaries to date indicate that treatment wetlands are particularly effective for consistent removal of BOD, TSS, and total nitrogen, and less effective for nitrification of ammonia (Knight 1993; Kadlec and Knight 1996). Reductions in the total phosphorus concentration of wastewater effluent have been shown to be highly variable.

Using constructed wetlands to effectively manage stormwater pollution presents an attractive option to many municipalities. Rochfort et al. (1997) reported some success in a constructed wetland pilot study of 
Table 3. Mechanisms for pollutant and nutrient removal (after Reddy and Burgoon 1996)

\begin{tabular}{ll}
\hline \hline Process & Effluent parameters \\
\hline $\begin{array}{l}\text { Physical: } \\
\text { Straining and } \\
\text { sedimentation }\end{array}$ & Suspended solids, particulate organic $\mathrm{C}, \mathrm{N}$ and $\mathrm{P}$ \\
$\begin{array}{l}\text { Chemical: } \\
\text { Adsorption }\end{array}$ & \\
& Dissolved organic compounds, anions $\left(\mathrm{PO}_{4}{ }^{3-}\right)$ and \\
Precipitation & cations (metals) \\
Volatilization & Amorganic $\mathrm{P}$, sulfides and metals \\
Biological: & \\
Microbial & \\
Respiration & $\left.\mathrm{NH}_{3}\right)$ and volatile organic compounds \\
Nitrification & $\mathrm{NH}_{4}-\mathrm{N}$ \\
Denitrification & $\mathrm{NO}_{3}-\mathrm{N}$ and $\mathrm{NO}_{2}-\mathrm{N}$ \\
Mineralization & Organic $\mathrm{N}^{3-}, \mathrm{SO}_{4}{ }^{2-}, \mathrm{HCO}^{3-}$ and volatile fatty acids \\
Assimilation & Nutrients \\
Plants & \\
Growth and uptake & Nutrients \\
Gas transport & $\mathrm{O}_{2}$ and related reactions \\
\hline
\end{tabular}

stormwater treatment in the City of Kingston, achieving average removal rates of $46 \%$ for suspended solids and $50 \%$ for copper. Using constructed wetlands to treat stormwater may present a greater challenge than municipal sewage treatment due to pulsed, nutrient-poor loading conditions. Treatment wetlands have also been shown to effectively polish leachate at the Sarnia Landfill site, with reductions of ammonia and nitrogen concentrations ranging from 52 to $90 \%$ (Higgins and Lugowski 1996).

The potential for wetlands to cost-effectively treat AMD has garnered a lot of attention in Canada and the United States. A study in Smithers, B.C., examined the long-term effectiveness of treating metal mine drainage using constructed wetlands (Sobolewski 1996). Winter conditions were not found to significantly decrease removal rates and the study concluded that long-term constructed wetland treatment was viable for low-strength influent water (0.3-1.0 ppm copper, $\mathrm{pH}>3)$, achieving a copper removal rate of greater than $98 \%$. Results from a pilot study of constructed wetland treatment of acid mine wastewater from Copper Cliff tailings in Sudbury also yielded high removal rates of acidity and metals, attaining $2.995 \mathrm{~g} \mathrm{~m}^{-3}$ day $^{-1}$ removal of acidity and $0.274 \mathrm{~g} \mathrm{~m}^{-3}$ day $^{-1}$ of nickel in August 1996 (Kalin and Smith 1997). A number of problems persist, however, relating to the long-term ability of constructed wetlands to treat high-strength mining effluent. Other problems with wetland treatment 
systems include the effect of low $\mathrm{pH}$ on aerobic wetland treatment and the occurrence of system failures resulting from soil plugging by metal hydroxides (Berezowsky 1996). Rather than address these problems directly, some Canadian researchers are experimenting with permeable active barriers, which also rely on microbial reductive processes to treat AMD (Benner et al. 1999).

\section{Constructed Wetland Design}

Design parameters of constructed wetlands are extremely variable because they depend on inflow water quality, local conditions and treatment objectives. Table 4 provides a summary of design features based on the 1993 North American Treatment Wetlands Database survey (Knight 1993).

Constructed wetlands are generally divided into two categories, free water surface wetlands (FWS) and subsurface flow wetlands (SSF). Although, both designs have been successfully employed to treat wastewater, there are advantages and disadvantages associated with each type (Kadlec 1996). Free water surface wetlands offer a greater 'natural' aesthetic value and lower construction and maintenance costs than subsurface flow wetlands (Campbell and Ogden 1999; Kadlec 1996). Maintenance costs are typically higher in SSF wetlands because they require a porous media, such as gravel, which can become blocked after several years of operation. The improved treatment efficiency of SSF wetlands, however, may outweigh the advantages of FWS wetlands (Rochfort 1995). Treatment performance levels are generally higher in SSF wetlands, especially in cold-weather climates, due to greater thermal protection and a greater surface area for microbial activity (Jenssen et al. 1996; Reed 1996). An additional advantage of SSF wetlands is that they offer a reduced risk of direct public contact with the constructed wetland system (Reed 1996; Rochfort 1995). According to Ford and Warner (2000), SSF wetland systems are a well-suited technology for Ontario's needs and markets for their competitive costs and their ability to achieve compliance with the environmental regulations of the Province of Ontario.

Other design criteria include water depth, cell configuration, inlet/outlet systems, botanical input, and soil composition (Gearheart 1992). These criteria must consider hydraulic loading rates, odours, tem-

Table 4. Design summary of constructed wetlands (after Knight 1993)

\begin{tabular}{lcc}
\hline \hline Design parameter & Average & Range \\
\hline Total area (ha) & 23 & $0.1-486$ \\
Hydraulic load, cm/day & 4.2 & $0.0001-19.5$ \\
Aspect ratio (length/width) & 17 & $0.7-84$ \\
Cell number & 2 & $1-17$ \\
\hline
\end{tabular}


perature, effluent criteria, and wildlife habitat creation goals (Pries 1996). The underlying idea of constructed wetland design is to maximize contact time and utilize the largest possible portion of the available treatment area. Sizing methods of constructed wetlands are often based on an evaluation of kinetic reaction rates using a mass balance approach, although other methods such as impervious surface area and volumetric load have also been employed. A detailed study of the affected area is essential to ensure the suitability of a treatment wetland site and to ensure that the desired treatment goals will be achieved (Taylor 1992). Site considerations include the hydrogeology, the size of the community being serviced, and climate. Figure 2 illustrates the design of typical wetland treatment systems.

\section{Advantages and Disadvantages of Constructed Wetland Treatment}

A wetland treatment approach is land intensive but much more energy efficient than engineered treatment plants, using natural solar and biophysical energy sources (Knight 1993). Compared to conventional treatment facilities, constructed wetlands provide a low-cost and low-maintenance alternative, although the costs associated with land acquisition can be significant (Campbell and Ogden 1999). For this reason, cost advantages conferred by constructed wetland treatment may be more evident in a rural context, as in northern Canada (Doku and Heinke 1995) or in smaller communities (Green 1994). Value-added benefits of constructed wetlands such as aesthetics, development of wildlife habitat, and the provision of recreational opportunities can also be deciding factors in implementing a wetland treatment approach (Amell and Eastlick 1996).

Proponents of treatment wetland technology consider wildlife habitat creation as an attractive and important net environmental benefit. The actual habitat value of the wetlands is debated, however, as a number of concerns have been identified regarding the negative impacts constructed wetlands may engender on wildlife and the environment. A review by Kelly-Hooper (1996) notes that the potentially lethal effects of trace metals, such as cadmium, can result in ecological imbalances in wetland environments. Ohlendorf (1996) recommends that an assessment of the potential effects of treatment wetlands on wildlife should be part of all constructed wetland project evaluations. He further proposes that ecological risk assessment provides a good framework for such evaluations. Chemicals that bioaccumulate in the food chain, such as $\mathrm{Hg}$, Se, or organochlorine pesticides, are of greatest concern (Ohlendorf 1996). The bioaccumulation of these toxins in the wetland environment could cause a range of adverse health effects in wildlife. A critical investigation of a delta marsh restoration project planned for the Don River in Ontario, revealed concerns related to the potential for chemical bio-concentration and bioaccumulation of urban contaminants through the aquatic community (Helfield and Diamond 1997). A recent study of Bishop et al. $(2000 \mathrm{a}, \mathrm{b})$ examined the link between the contaminant concentrations and wildlife communities in 15 stormwater detention ponds from Guelph and the Greater Toronto Area. The authors concluded that although wildlife made use of the stormwater detention ponds, the species rich- 
(a)

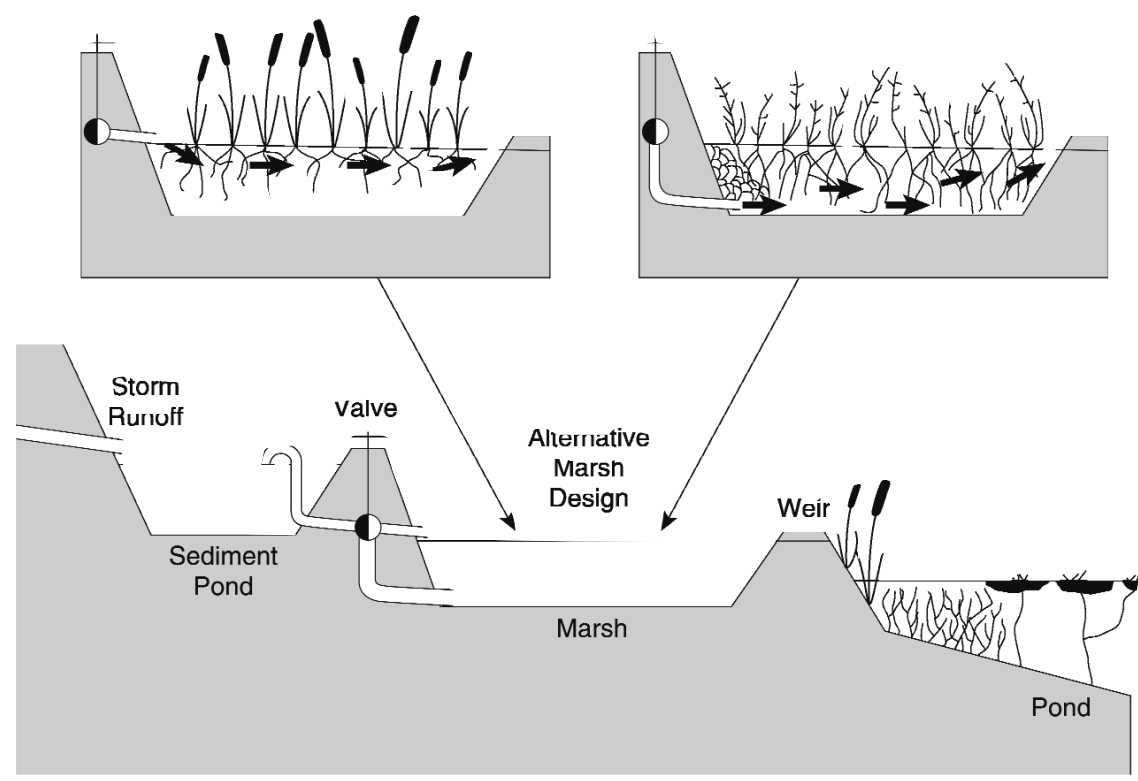

Fig. 2. Design of constructed wetlands (a) free water surface (FWS) wetlands, and (b) subsurface flow (SSF) wetlands (from Taylor \& Associates 1992).

ness at almost all ponds was low to moderate, indicating that the ponds did not provide high-quality habitat for wildlife. The same survey (Bishop et al. 2000a,b) showed statistically lower hatching success of northern leopard frog eggs and longer time for the larvae to metamorphose at two stormwater ponds. Also, statistically fewer tadpoles survived to metamorphosis in one stormwater pond. More research is certainly warranted on the environmental fate of toxins introduced into treatment wetlands.

Another disadvantage of constructed wetlands is that they consist of open systems, attracting wildlife that could potentially complicate management of the constructed wetland and reduce treatment efficiency (Knight 1993). For example, beavers, muskrats, and crayfish populations have all been known to decimate wetland vegetation, and mosquitoes provide an unwanted nuisance (Campbell and Ogden 1999). Rochfort (1995) reported that crayfish grazing exerted a deleterious influence on the nutrient assimilation as a consequence of reduced wetland plant density. Cages or "in-marsh exclosures" have been used in wetland restoration projects such as Cootes Paradise to prevent uprooting of newly planted vegetation by carp and muskrats (Sproule-Jones and White 1997). Similar measures might be used in constructed wetlands.

The long-term success of wetland treatment systems is also contested. Lan et al. (1992) note the possibility that once all of the available sites for complexation are used up, the ionic wetland soil's capacity for assimilation will be significantly reduced. A number of studies have shown, however, 
that concentrations of metals in plant tissue and soils do not increase significantly compared to baseline values after several years of wetland operation (Crites et al. 1997). The life expectancy of treatment wetlands largely depends on the type and strength of the wastewater being treated. Life expectancies ranging from decades for high-strength industrial effluent to centuries for municipal effluent have been reported (Pries 1996). The variability associated with treatment performance is another disadvantage of treatment wetlands where contaminant levels are strictly regulated.

\section{Cold Weather Treatment Performance}

Although warmer regions offer a greater opportunity for successful wetland treatment, many studies have shown that wetland treatment is feasible in colder regions (Wittgren and Maehlum 1997; Pries 1996). The major engineering concerns in cold climates are related to the thermal consequences for biologically or microbiologically mediated treatment processes, in addition to hydrologic and hydraulic issues, especially ice formation (Wittgren and Maehlum 1997). Pioneering work in Listowel, Ontario, found that allowing an ice layer to form on the surface of the wetland and then dropping the water level provided sufficient insulation to prevent freeze-up (Herskowitz 1986). Other approaches of reducing heat loss include the insertion of an insulating material, such as polystyrene, along the wetland perimeter (Jenssen et al. 1996). Microbially mediated processes, such as nitrogen and BOD removal, are temperature sensitive and are therefore the subject of considerable concern with respect to cold weather performance. Studies in Norway showed that temperature effects were significant for nitrogen reduction, whereas winter removal performance of other parameters was remarkably comparable to summer levels (Jenssen et al. 1996). BOD removal is at least partially attributed to microbial processes, although Reddy and Burgoon (1996) conclude that sedimentation is the dominant BOD removal mechanism based on a lack of evidence of decreased removal efficiency in cold climates. Additional challenges to using treatment wetlands in northern areas of Canada include permafrost, low precipitation, extreme temperatures, and 24 hours of darkness (Pries 1996).

Many northern systems store water for the duration of the non-growing season to avoid problems related to diminished treatment performance (Pries 1996). For example, a dairy operation in Embrun, Ontario, stores farmstead runoff during the winter in a storage lagoon, and then treats the runoff using constructed wetlands during the growing season (Weil et al. 1996). Wetland plants provide only a temporary removal mechanism in northern systems. During fall die-back, some nutrients are re-released into the environment from decaying vegetation. Rochfort et al. (1997) found, however, that removal rates of orthophosphate could be maintained above 39\% even during fall die-back in a subsurface flow wetland. Moreover, constructed wetlands can be used to alleviate summer algal blooms from municipal effluents because plant uptake occurs during the summer when eutrophication is problematic (Pries 1994; Thorson 
et al. 1994). A possible solution to nutrient re-release involves the harvesting of wetland plants. A study by Lakshman (1994) on Canadian constructed wetlands notes that biomass harvested from municipal treatment wetlands is suitable for animal feed and heating fuel. The harvested material could also be reused through composting or fibreboard production (Rochfort 1995).

\section{Research Needs and Directions}

For treatment wetlands to gain wider acceptance in Canada, more specific guidelines and Best Management Practices (BMPs) regarding constructed wetland design, operation, maintenance, and cost effectiveness need to be established (Wittgren and Maehlum 1997). Before these management and engineering concerns can be addressed, however, a greater understanding of nutrient pathways and biogeochemical processes operating within the wetland environment is needed. This research would foster the development of more effective predictive models and help define removal kinetics as a function of plant and microbe type, biomass, detention time, and temperature (Campbell and Ogden 1999; Cole 1998).

Further research on constructed wetland treatment performance in cold climates is needed to adequately assess the feasibility of widespread implementation of treatment wetlands in Canada. For example, Doku and Heinke (1995) conclude that the municipal treatment using wetlands is feasible in northern Canada, although more monitoring data is needed from existing northern treatment wetland systems. A 1995 EPA assessment of the technology identified the following research needs: 1) more monitoring data from full-scale systems receiving medium to high organic loads, 2) the role of dissolved oxygen concentrations in removal of BOD and total nitrogen, and 3) the effects of different plant communities on performance (Cole 1998). Other research needs include assessment of the effect of wetland configuration, plant harvesting, and bottom substrate on the degree of treatment (Campbell and Ogden 1999).

Several studies in Canada are being conducted to optimize treatment performance. A study conducted at Niagara-on-the-Lake is experimenting with different constructed wetland cell configurations and vertical flow designs to improve root bed aeration and treatment efficiency (Lemon et al. 1996). Another research thrust is to improve removal rates by modifying root bed media. A lab-scale constructed wetland at Brock University found that optimum removal rates of $\mathrm{P}$ were achieved using an iron/sand mixture (Brindle et al. 1996).

Lastly, more research is needed to assess the effects of contaminants on the biota, for which these treatment facilities function as habitats.

\section{Conclusions and Recommendations}

Despite the many factors threatening Canada's wetland resources, the social and environmental importance of wetland ecosystems is becoming 
increasingly evident in Canada. Recent policy developments and increased public recognition of wetland benefits reflect these changing attitudes towards wetlands, providing reason for optimism. Wetland research has recognized the critical role natural wetlands occupy in water purification, life support, flood control, storm and shoreline protection, carbon sequestration, and nutrient cycling. Wetlands benefit a number of sectors of Canadian life, supporting a number of viable Canadian industries and providing natural areas for recreational usage. A number of research gaps, relating to anthropogenic impacts, wetland valuation, modelling of wetland dynamics, and the implementation of constructed wetlands for wastewater treatment, have been identified throughout this review. Ecological engineering is an expanding science, and will eventually lead to effective predictive modelling of contaminant removal performance and a paradigm shift. Wetland plants and sediment provide a substrate for a variety of biological and chemical processes, such as microbial degradation and precipitation, which contribute to improved water quality.

A review of the available case studies on cold weather treatment indicates that constructed wetland technology is feasible in Canada, particularly for municipal treatment, although further monitoring data is needed to optimize wetland design and ensure that the MOEE effluent quality standards are consistently met. Very few failed treatment wetland projects are mentioned in the literature. Measures to compensate for fall die-back such as harvesting may also require development.

This review also identified many pressures and threats to the sustainability of Canada's wetlands. A substantial number of Canada's wetlands have been converted for alternative land uses. Although ecologically resilient, Canada's remaining wetlands have been seriously impacted by urban development and agricultural practices, suffering degraded water quality and reduced species richness.

\section{Acknowledgment}

We thank L. Dunn, S. Brown and anonymous reviewers for valuable comments and constructive criticism.

\section{References}

Agriculture Canada. 1999. 1998/1999 Canadian fruit situation and trends (including apples, tree fruits, and berries). Agriculture and Agri-Food Canada, Market Industry and Service Branch, Ottawa, Ont.

Ali S. 1992. Purple loosestrife in Alberta. National workshop on purple loosestrife management.

Amell B, Eastlick BK. 1996. Design for multiple benefit constructed wetlands. In Constructed wetlands in cold climates. Proceedings of the symposium held at the Niagara-on-the-Lake, Ontario, Canada, June 4-5, 1996.

Armentanao TV, Menges C. 1986. Patterns of change in the carbon balance of organic-soil wetlands of the temperate zone. J. Ecol. 74:755-774.

Bardecki MJ. 1999. Wetlands and economics: an annotated review of the literature, 1988-1998. Environment Canada. 
Batt BDJ, Anderson MG, Anderson CD, Caswell FD. 1989. The use of prairie potholes by North American ducks, p. 204-227. In van der Valk AG (ed.), Northern prairie wetlands. Iowa State University Press, Ames, Iowa.

Benner SG, Blowes DW, Gould WD, Herbert Jr RB, Ptacek CJ. 1999. Geochemistry of a permeable reactive barrier for metals and acid mine drainage. Environ. Sci. Tech. 33(16):2793-2799.

Berezowsky M. 1996. Constructed wetlands for remediation of urban waste waters, p. 203-213. In Eyles N (ed.), Environmental geology of urban areas.

Bishop CA, Struger J, Barton DR, Shirose LJ, Dunn L, Lang AI, Shepherd D. 2000a. Contamination and wildlife communities in stormwater detention ponds in Guelph and the Greater Toronto Area, Ontario, 1997 and 1998. Part I - wildlife communities. Water Qual. Res. J. Canada 35(3):399-435.

Bishop CA, Struger J, Shirose LJ, Dunn L, Campbell D. 2000b. Contamination and wildlife communities in stormwater detention ponds in Guelph and the Greater Toronto Area, Ontario, 1997 and 1998. Part II - contamination and biological effects of contamination. Water Qual. Res. J. Canada 35(3):437-474.

Brindle ID, McLaughlin R, Rozema L. 1996. Investigations into phosphorus removal by constructed wetlands: root bed media modifications. In Constructed wetlands in cold climates. Proceedings of the symposium held at the Niagara-on-the-Lake, Ontario, Canada, June 4-5, 1996.

Campbell CS, Ogden MH. 1999. Constructed wetlands in the sustainable landscape. John Wiley \& Sons, Inc., New York.

Cole S. 1998. The emergence of treatment wetlands. Environ. Sci. Tech. 32(9):218.

Crites RW, Dombeck GD, Watson RC. 1997. Removal of metals and ammonia in constructed wetlands. Water Environ. Res. 69:132-135.

Crowder AA, Bristow JM. 1988. The future of waterfowl habitats in the Canadian lower Great Lakes wetlands. J. Great Lakes Res. 14(1):115-127.

Dahme H. 1989. Wetlands protection in Canada, p. 33-37. In Bardecki MJ, Patterson N (ed.), Wetlands: inertia or momentum. Federation of Ontario Naturalists. Don Mills.

Derksen AJ, Gillies DG. 1985. The seasonal utilization of the Saskeram marshes by fish populations and its significance to the fisheries resources of the Saskatchewan River Delta in Manitoba, with special reference to northern pike. Report No. 85-10. Manitoba Department Natural Resources, Fisheries Branch MS.

Devito KJ. 1995. Sulphate mass balances of Precambrian Shield wetlands: the influence of catchment hydrogeology. Can. J. Fish. Aquat. Sci. 52(8):1750-1760.

Doku I, Heinke GW. 1995. Potential for greater use of wetlands for waste treatment in northern Canada. J. Cold Regions Eng. 9(2):75-88.

Dunster K. 1990. Exotic plant species management plan, Point Pelee National Park. Report prepared for Parks Canada, Ontario Region.

Elliot ML, Mulamoottil G. 1992. Agricultural and marsh land uses on Walpole Island: profit comparisons. CWRJ 17:111-119.

Findlay CS, Houlahan J. 1997. Anthropogenic correlates of species richness in southeastern Ontario wetlands. Conservation Biol. 11( 4):1000-1009.

Ford GI, Warner BG. 2000. Subsurface flow treatment wetlands in Ontario, Canada. Millennium Wetland Event, Quebec City, Canada, August 6-12, 2000.

Franzen LG. 1992. Can Earth afford to lose the wetlands in the battle against the increasing greenhouse effect? International Peat Congress, p. 1-17.

Fyson A, English MW, Kalin M. 1991. Effect of foliar fertilization on Typha latifolia L. growing in acid mine drainage. In Webb FJ (ed.), Proceedings of the 18th annual conference on wetlands restoration and creation. Tampa, Florida, Hillsborough Community Coll. 
Gearheart RA. 1992. Use of constructed wetlands to treat domestic wastewater, City of Arcata, California. Water Sci. Technol. 26(7-8):1625-1637.

Glooschenko WA. 1978. Sedimentary geochemistry of a Lake Ontario urban marsh. In Rukavina NA (ed.), Proceedings of 2nd workshop on Great Lakes coastal erosion and sedimentation.

Gore \& Storrie Limited. 2000. Wetlands for water quality management. Statement of Qualifications.

Gorham E. 1991. Northern peatlands: role in the carbon cycle and probable responses to climatic warming. Ecol. Appl. 1(2):182-195.

Graniero PA, Price JS. 1999. The importance of topographic factors on the distribution of bog and heath in a Newfoundland blanket bog complex. Cantena 26(3):233-254.

Greipsson S, Crowder AA. 1992. Amelioration of copper and nickel toxicity by iron plaque on roots of rice (Oryza sativa). Can. J. Bot. 70(4):824-830.

Green B. 1994. Constructed wetlands are big in small communities. Water Environ. Technol. 6(2):51-55.

Hammer DA. 1991. Creating freshwater wetlands. Chelsea, Michigan, Lewis Publishers.

Heagle DJ, Aravena RO, Warner B, Devito K, Fitzgerald D. 1998. Sources of dissolved organic carbon for denitrification in a riparian wetland. Geological Society of America. Abstracts with programs - Geological Society of America, no. 30. Geological Society of America (GSA), Boulder, Colorado, United States.

Helfield JM, Diamond ML. 1997. Use of constructed wetlands for urban stream restoration: a critical analysis. Environ. Manage. 21(3):329-341.

Herdendorf CE. 1992. Lake Erie coastal wetlands: an overview. J. Great Lakes Res. 18(4):566-562.

Herskowitz J. 1986. Listowel artificial marsh project. External Research Projects, Part B, Water Quality Research. Technology Transfer Conference: proceedings.

Higgins J, Lugowski A. 1996. The use of a natural forested wetland for landfill leachate polishing in a cold climate. In Constructed wetlands in cold climates. Proceedings of the symposium held at the Niagara-on-the-Lake, Ontario, Canada, June 4-5, 1996.

Hvenegaard GT, Butler JH, Krystofiak DK. 1989. Economic values of bird watching at Point Pelee National Park, Canada. Wildlife Soc. Bull. 17:526-531.

Jenssen PD, Maehlum T, Zhu T. 1996. Design and performance of subsurface flow constructed wetlands in Norway. In Constructed wetlands in cold climates. Proceedings of the symposium held at the Niagara-on-the-Lake, Ontario, Canada, June 4-5, 1996.

Kadlec R. 1996. Physical processes in constructed wetlands. In Constructed wetlands in cold climates. Proceedings of the symposium held at the Niagaraon-the-Lake, Ontario, Canada, June 4-5, 1996.

Kadlec RH. 1992. Sediment processes in wetlands. In Agronomy abstracts. ASA, Madison, Wisconsin, 45.

Kadlec RH, Knight RL. 1996. Treatment wetlands. Lewis Publishers. Boca Raton, Florida.

Kalin M, Smith MP. 1997. Microbial acid reduction in sediments - concepts and application. Fourth international conference on acid rock drainage, Vancouver.

Kalin M, Scribailo RW. 1989. Morphological/anatomical investigation of cattail transplants and bog vegetation: final report. 
Kelly-Hooper F. 1996. Bioavailability of cadmium to benthic invertebrates: constructed wetlands for storm water treatment. Proceedings from the constructed wetlands in cold climates symposium, Niagara-on-the-Lake.

Knight RL. 1993. Operating experience with constructed wetlands for wastewater treatment. TAPPI J. 76(1):109-112.

Knight RL, Kadlec RH. 2000. Constructed treatment wetlands - a global technology. Water 21:57-58.

Krieger KA, Klarer DM, Heath RT, Herdendorf CE. 1992. A call for research on Great Lakes coastal wetlands. J. Great Lakes Res. 18(4):525-528.

Lakshman G. 1994. Design and operational limitations of engineered wetlands in cold climates - Canadian experience, p. 399-409. In Mitsch WJ (ed.), Global wetlands. Elsevier Science.

Lan C, Chen G, Li L, Wong MH. 1992. Use of cattails in treating wastewater from a $\mathrm{Pb} / \mathrm{Zn}$ mine. Environ. Manage. 16(1):75-80.

Lemon E, Bis G, Rozema L, Smith I. 1996. SWAMP pilot scale wetlands - design and performance. In Constructed wetlands in cold climates. Proceedings of the symposium held at the Niagara-on-the-Lake, Ontario, Canada, June 4-5, 1996.

McGarry PT, Pries J. 2000. Constructed wetlands for feedlot runoff treatment in Manitoba. Millennium Wetland Event, Quebec City, Canada, August 6-12, 2000.

McKenna G, Gregoriou A, Pries J. 2000. Ontario power generation (Nanticoke) treatment wetland. Millennium Wetland Event, Quebec City, Canada, August 6-12, 2000.

Mitsch WJ, Gosselink JG. 1986. Wetlands. Van Nostrand Reinhold Co., New York.

Mitsch WJ, Gosselink JG. 2000. Wetlands. John Wiley and Sons, Inc., New York.

Mitsch WJ, Wilson RF. 1996. Improving the success of wetland creation and restoration with know-how, time and self-design. Ecol. Appl. 6(1):77-83.

Moore TR, Roulet NT, Waddington JM. 1998. Uncertainty in predicting the effect of climatic change on the carbon cycling of Canadian peatlands. Climatic Change 40:229-245.

Neill C. 1995. Seasonal flooding, nitrogen mineralization and nitrogen utilization in a prairie marsh. Biogeochemistry 30(3):171-189.

North American Wetlands Conservation Council. 1996. Canadian peat moss and the environment.

North American Wetlands Conservation Council (NAWCC) Canada. A wetland conservation vision for Canada. http:/ / www.wetlandscanada.org/vision.pdf.

NWWG (National Wetlands Working Group). 1987. The Canadian wetland classification system. Ecological Land Classification Series, Inland Waters/Land Directorate, Environment Canada, Ottawa.

NWWG (National Wetlands Working Group). 1997. The Canadian wetland classification system, 2nd ed., Rubec CDA and Warner BG (ed.). Waterloo, Ontario, Wetland Research Centre Publication. 68 p.

Ohlendorf HM. 1996. Ecological risk assessment for constructed wetlands. In Constructed wetlands in cold climates. Proceedings of the symposium held at the Niagara-on-the-Lake, Ontario, Canada, June 4-5, 1996.

Patrick WH. 1994. From wastelands to wetlands. J. Environ. Qual. 23:892-896.

Price JS. 1997. Soil moisture, water tension, and water table relationships in a managed cutover bog. J. Hydrol. 202:21-32.

Price JS, Waddington JM. 1999. Progress in Canadian wetland hydrology, 1995-1998. p. 1-13. 
Pries JH. 1994. Wastewater and stormwater applications of wetlands in Canada. North American Wetlands Conservation Council (Canada), Ottawa, Ontario.

Pries JH. 1996. Constructed wetland treatment systems in Canada. In Constructed wetlands in cold climates. Proceedings of the symposium held at the Niagara-on-the-Lake, Ontario, Canada, June 4-5, 1996.

Reddy KR, Burgoon PS. 1996. Influence of temperature on biogeochemical processes in constructed wetlands: implications to wastewater treatment. In Constructed wetlands in cold climates. Proceedings of the symposium held at the Niagara-on-the-Lake, Ontario, Canada, June 4-5, 1996.

Reddy KR, Gale PM. 1994. Wetland processes and water quality: a symposium overview. J. Environ. Qual. 23:875-877.

Reddy KR, Kadlec RH, Flaig E, Gale PM. 1999. Phosphorus retention in streams and wetlands: a review. Environ. Sci. Tech. 29(1):83-146.

Reed SC, Middlebrooks EJ, Crites RW. 1993. Natural systems for waste management and treatment. Second ed. McGraw-Hill Inc., New York.

Reed SC. 1996. Thermal aspects of constructed wetland system design. In Constructed wetlands in cold climates. Proceedings of the symposium held at the Niagara-on-the-Lake, Ontario, Canada, June 4-5, 1996.

Reimold RJ, McBrien MA. 1997. Evaluating wetlands treatment systems for Alexandria, Egypt. Water Environ. Technol. 9(3):29-34.

Richardson C, Qian S. 1999. Long-term phosphorus assimilative capacity in freshwater wetlands: a new paradigm for sustaining ecosystem structure and functions. Environ. Sci. Tech. 33:1545-1551.

Richman M. 1997. Spring flood tied to wetlands destruction. Water Environ. Technol. 9(7):25-26.

Rochfort Q. 1995. Engineered biosystems for stormwater contaminant removal. M.Sc. thesis, Department of Civil Engineering, Queen's University, Kingston, Ontario. 167 p.

Rochfort QJ, Anderson BC, Crowder AA. 1997. Field-scale studies of subsurface flow constructed wetlands for stormwater quality enhancement. Water Qual. Res. J. Canada 32(1):101-117.

Rubec C. 1992. Canadian wetland policy promotes conservation. Water Environ. Technol. 4:30.

Rubec C, Lynch-Stewart P, Wickware GM, Kessel-Taylor I. 1988. Wetland utilization in Canada, p. 379-412. In Wetlands of Canada. National Wetlands Working Group. Ottawa: Sustainable Development Branch, Environment Canada, and Polyscience Publications Inc.

Smith MP, Kalin M. 2000. Floating wetland covers in biological wastewater treatment systems. Millennium Wetland Event, Quebec City, Canada, August 6-12, 2000.

Serodes JB, Normand D. 1999. Phosphorus removal in agricultural wastewater by a recently constructed wetland. Can. J. Civ. Eng. 26:305-311.

Sobolewski A. 1996. Metal species indicate the potential of constructed wetlands for long-term treatment of metal mine drainage. Ecol. Eng. 6:259-271.

Sobolewski A. 1997. The capacity of natural wetlands to ameliorate water quality: a review of case studies. Fourth International Conference on Acid Rock Drainage, Vancouver.

SOCE. 1991. The state of Canada's environment. The Government of Canada, Ottawa.

Sproule-Jones M, White B. 1997. The McMaster eco-research program for Hamilton Harbour, final report 1993-1996, McMaster University, Hamilton, Ont. 
Tarnocai C. 1998. The amount of organic carbon in various soil orders and ecological provinces in Canada, p. 81-92. In Lal R, Kimble JM, Follet RF, Stewart BA (ed.), Soil processes and the carbon cycle. CRC Press, Boca Raton, Fla.

Taylor ME \& Associates. 1992. Constructed wetlands for stormwater management, PIBS 1907 E01. Ontario Ministry of Environment and Energy.

Thorson R, Lorenz W, Arber R. 1994. Cold weather wetlands constructed. Water Environ. Technol. 6:25-26.

Van der Kamp G, Hayashi M. 1998. The groundwater recharge function of small wetlands in the semi-arid northern prairies. Great Plains Res. 8:39-56.

Vitousek PM, Abner J, Horvath RW, Likens GE, Matson PA, Schindler DW, Schlessinger WH, Tilman GD. 1997. Human alteration of the global nitrogen cycle: causes, and consequences. Issues in Ecology 1. Ecological Society of America, Washington D.C.

Warner BC, Rubec CDA (ed.). 1997. The Canadian wetland classification system. National Wetlands Working Group, Wetlands Research Centre, University of Waterloo, Waterloo, Ontario.

Weil C, Kollaard W, Malcolm I, Vanclief L. 1996. Constructed wetland system for treatment of farmstead runoff, Embrun, Ont. In Constructed wetlands in cold climates. Proceedings of the symposium held at the Niagara-on-theLake, Ontario, Canada, June 4-5, 1996.

Williams M. 1990. Wetlands: a threatened landscape. The Alden Press, Oxford, Great Britain.

Wittgren HB, Maehlum T. 1997. Wastewater treatment wetlands in cold climates. Water Sci. Technol. 35(5):45-53.

Young DA, Thompson JP. 1990. Prairie pothole wetlands: functions and evaluation. Wetlands are not wastelands project report 7, Wildlife Habitat Canada, Environment Canada, Ottawa.

Zoltai SC. 1988. Wetland environments and classification. Wetlands in Canada. National Wetlands Working Group, 4-26. Ottawa: Sustainable Development Branch, Environment Canada, and Polyscience Publications Inc.

Zoltai SC, Vitt DH. 1995. Canadian wetlands: environmental gradients and classification. Environments and Classification. Vegetatio 118:131-137. 